\title{
波形鋼板ウェブ橋における埋込み接合部の 耐久性の検討
}

\author{
小野聖久 ${ }^{* 1} \cdot$ 大城壮司 ${ }^{* 2} \cdot$ 桜田道博*3 $・$ 大浦 隆*4
}

概 要 波形鋼板ウェブ橋における埋込み接合部の腐食耐久性を検討するため，(1)シーリング材の有無，(2)鋼とコンク リートとの付着，および(3)塗装のコンクリート中への埋込み深さ等をパラメータとした供試体を製作し，促進腐食実験を 行った。実騒の結果，シーリング材の有無と塗装の埋込み深さは埋込み接合部の腐食耐久性に大きな影響を及ぼすこと， およびシーリング材を設置することにより埋込み接合部の腐食耐久性は大きく向上すること等が確認された。

キーワード：波形鋼板ウェブ，埋込み接合，耐久性，複合サイクル試験，シーリング材，EPMA，塩化物イオン濃度

1.はじめに

近年，プレストレストコンクリート橋（以降，PC 橋） の軽量化，耐震性の向上，施工の合理化，およびコスト 縮減を図るため，波形鋼板ウェブを有する複合 PC 橋 (以降，波形鋼板ウェブ橋）の実績が増えている1。日本 で初めての波形鋼板ウェブ橋は1993 年に完成した新潟 県の新開橋 (2 主単純箱桁橋, 支間 $30.0 \mathrm{~m})^{2)}$ で, 続い て，1996 年に秋田県の銀山御幸橋（5 径間連続橋, 最大 支間 $45.0 \mathrm{~m})^{3)}$ が完成した。高速道路橋では, 東海北陸 自動車道の本谷橋（3 径間連続ラーメン橋，最大支間 $97.2 \mathrm{~m}$ ) で初めて採用され，1998年に完成した(写真-1)。 その後, 活発な研究開発が行われ, 現在では 80 橋を超 える橋梁が建設されており，高速道路橋において波形鋼 板ウェブ橋は一般的な橋梁形式のひとつとなっている。 波形鋼板ウェブ橋におけるコンクリート床版と波形鋼

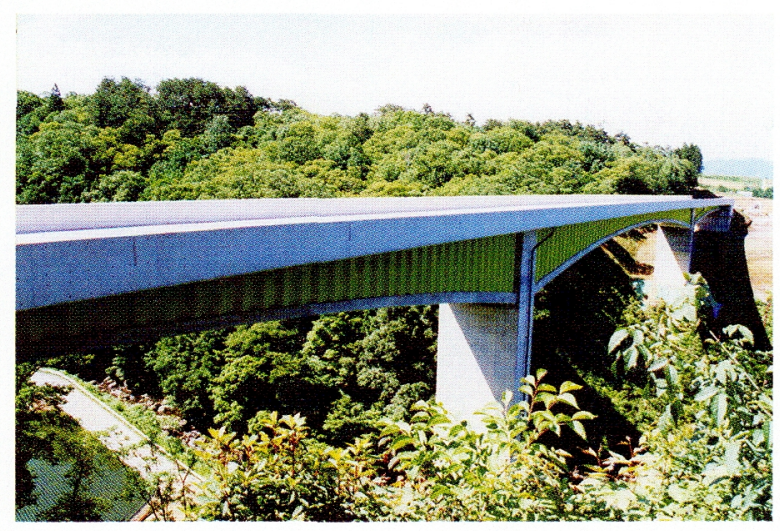

写真-1＼cjkstart波形鋼板ウェブ橋（本谷橋）

*1 おの・きよひさ/中日本高速道路㑣 中央研究所 道路研究部 橋 梁研究室 (正会員)

*2 おおしろ・たけし/中日本高速道路秼 中央研究所 道路研究部 橋梁研究室

＊3ささくらだ・みちひろ/(祀プレストレスト・コンクリート建設業 協会 (正会員)

＊4おおうら・たかし/社プレストレスト・コンクリート建設業協 会 (正会員)
板ウェブとの接合部は構造上, 最も重要な構造部位であ り, 図-1のと抢りいくつかの種類が開発されている。 このなかで，埋込み接合はフランジプレートを必要とし ないため疲労耐久性 (j) およびコストの面で有利な接合 方法といえるが，埋込み接合では波形鋼板ウェブが直接 コンクリートに埋め込まれていることから（写真-2）,

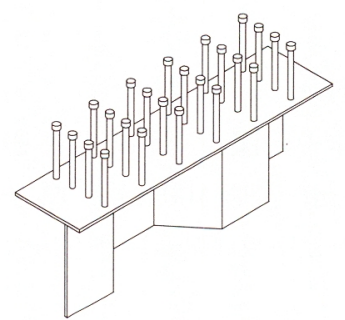

a) スタッドジベル接合

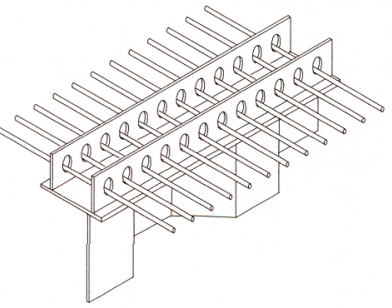

c）孔あき鋼板ジベル接合

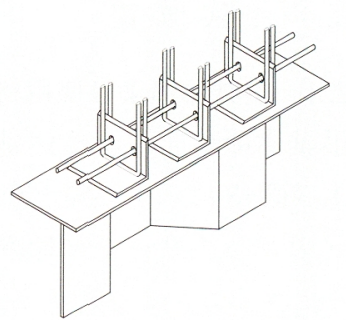

b) アングルジベル接合 図-1＼cjkstart波形鋼板ウェブ橋の接合方法

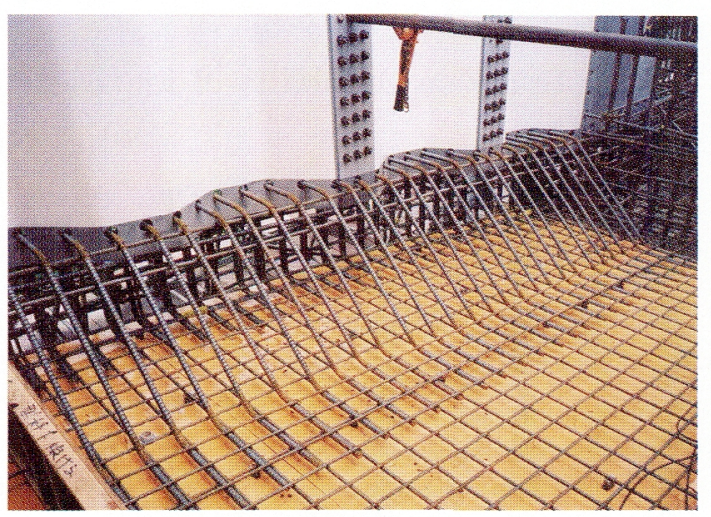

写真-2 埋込み接合部（打設前） 


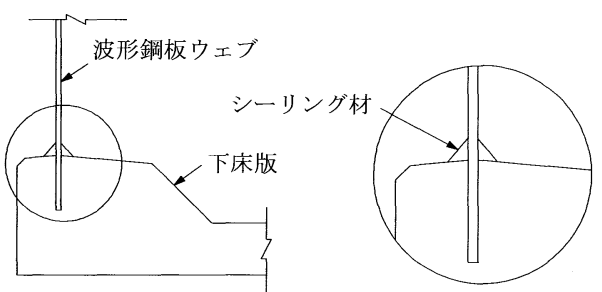

図-2 埋込み接合部の防食対策

特に下床版との接合部では鋼板とコンクリートとの境界 から水が浸入し, 埋め込まれた鋼板が腐食することが懸 念される。これまでの実績では図-2のようにウェブと コンクリートとの境界部をシーリング材で防水処理する ことで腐食対策を実施しているが，埋込み接合部の腐食 メカニズムやシーリング材が接合部の腐食耐久性に及ぼ す効果は明らかになっていないのが現状である。

そこで，本研究では，埋込み接合をモデル化した供試 体により促進腐食試験（複合サイクル塩水噴霧試験）を 実施し，(1)シーリング材の有無，(2)コンクリートと鋼材 との付着, および(3)塗装のコンクリート中への埋込み長 等の要因が，埋込み接合部の腐食耐久性に及ぼす影響を 検討した。

\section{2. 実 験 概 要}

\section{1 供試体および使用材料}

供試体の諸元および供試体一般図をそれぞれ，表-1 および図-3に示す。幅 $100 \mathrm{~mm}$ ，高さ $100 \mathrm{~mm}$ ，厚さ 60 $\mathrm{mm}$ のコンクリートに厚さ $9 \mathrm{~mm}$ の鋼板を埋め込むこ

\section{表-1＼cjkstart供試体の諸元}

\begin{tabular}{c|c|c|c|c|c}
\hline \multirow{2}{*}{ 名 称 } & \multirow{2}{*}{ 付着 } & \multicolumn{2}{|c|}{ 鋼板の塗装 } & \multirow{2}{*}{$\begin{array}{c}\text { 塗装の } \\
\text { 埋込み深さ }\end{array}$} & $\begin{array}{c}\text { シーリング } \\
\text { 材 }\end{array}$ \\
\cline { 3 - 4 } & & 埋込部 & 露出部 & 俚 \\
\hline 供試体 1 & 有 & プライマー & 塗装 & $20 \mathrm{~mm}$ & 有 \\
\hline 供試体 2 & 有 & プライマー & 塗装 & $20 \mathrm{~mm}$ & 無 \\
\hline 供試体 3 & 有 & 裸 & 塗装 & $20 \mathrm{~mm}$ & 無 \\
\hline 供試体 4 & 無 & 裸 & 塗装 & $20 \mathrm{~mm}$ & 無 \\
\hline 供試体 5 & 無 & 裸 & 塗装 & $0 \mathrm{~mm}$ & 無 \\
\hline 供試体 6 & 無 & 裸 & 塗装 & $-5 \mathrm{~mm}$ & 無 \\
\hline 供試体 7 & 無 & 裸 & 塗装 & $-5 \mathrm{~mm}$ & 有 \\
\hline 供試体 8 & 有 & 裸 & 裸 & - & 無 \\
\hline
\end{tabular}

とで，埋込み接合部をモデル化した。供試体は，(1)コン クリートと鋼材との付着の有無, (2)シーリング材の有無, および(3)塗装の埋込み深さ等をパラメータとした 7 種類 (供試体 1〜 7) と, 過去の腐食実験 ${ }^{8)}$ との比較のため無 塗装の鋼板を使用した 1 種類（供試体 8）の合計 8 種類 とした。

コンクリートと鋼材との付着については，実際の橋梁 では，コンクリートジベル（鋼板の孔に充填されたコン クリート）や貫通鉄筋（鋼板の孔を貫通した鉄筋）によ りコンクリート床版と波形鋼板ウェブとは基本的には一 体化していると考えられるが，乾燥収縮や想定以上の荷 重により，コンクリート亡鋼板の付着が切れる可能性が ある。そこで付着なしの供試体は，材齢 1 日において外 力を加え，コンクリートと鋼材とをわずかにずらすこと で付着を切断した。

塗装の埋込みについては, 供試体 8 以外の鋼材はコン クリートに埋め込まれる部分を除き，薄膜重防食塗装系 で塗装し, 塗装のコンクリート中への埋込み長は $20 \mathrm{~mm}$, $0 \mathrm{~mm}$ ，抢よびー5 $\mathrm{mm}$ とした。埋込み長 $20 \mathrm{~mm}$ は実際 の施工事例より浅いが，これは複合サイクル試験機のサ イズにより供試体寸法が制約されたためである。また，

供 試 体

塗装範囲

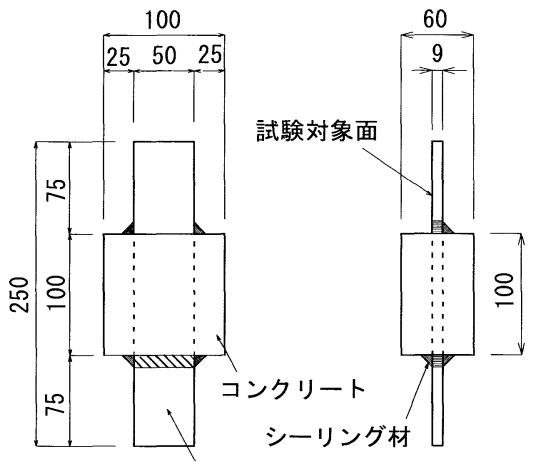

埋込み深さ $20 \mathrm{~mm}$

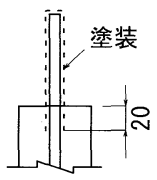

埋込み深さ0mm

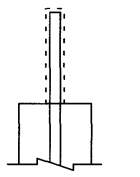

鋼材 (SM490)

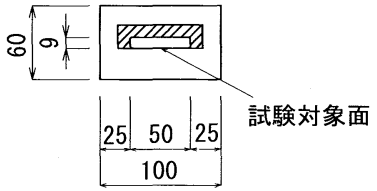

埋込み深さ $-5 \mathrm{~mm}$

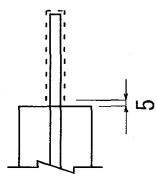

図-3 供試体一般図

Study on Durability of Embedded Connection for Prestressed Concrete Bridges with Corrugated Steel Webs

By K. Ono, T. Ohshiro, M. Sakurada and T. Ohura

Concrete Journal, Vol.44, No.8, pp.23 29, Aug. 2006

Synopsis In order to confirm the corrosion of embedded connection in prestressed concrete bridges with corrugated steel webs, accelerated corrosion experiment was carried out with the specimens modeled from the embedded connection. As a result, the durability of embedded connection is increased by sealing the interface between steel and concrete and increasing the depth of painting into concrete.

Keywords : corrugated steel web, embedded connection, durability, accelerated corrosion test, sealant, electron probe $\mathrm{X}$-ray microanalysis, density of chloride ions 
表-2 使用材料

\begin{tabular}{|c|c|c|}
\hline 材 料 & 記号 & 摘 要 \\
\hline セメント & $\mathrm{C}$ & 早強セメント, 密度 $3.14 \mathrm{~g} / \mathrm{cm}^{3}$ \\
\hline 練混ぜ水 & W & 上水道水 \\
\hline 細骨材 & S & $\begin{array}{l}\text { 砕砂, 表乾密度 } 2.57 \mathrm{~g} / \mathrm{cm}^{3} \text {, 吸水率 } 2.59 \% \text {, } \\
\text { FM 2.95 }\end{array}$ \\
\hline 粗骨材 & G & $\begin{array}{l}\text { 砕石, 表乾密度 } 2.68 \mathrm{~g} / \mathrm{cm}^{3} \text {, 吸水率 } 0.52 \% \text {, } \\
\text { 最大寸法 } 15 \mathrm{~mm}\end{array}$ \\
\hline 高性能减水剂 & SP & ポリカルボン酸系 \\
\hline $\mathrm{AE}$ 剂 & $\mathrm{AE}$ & アルキルエーテル系 \\
\hline 鋼板 & - & $\mathrm{SM} 490 \mathrm{~A}, \quad 250 \times 50 \times 9 \mathrm{~mm}$ \\
\hline シーリング材 & - & シリコーン系（1成分形） \\
\hline
\end{tabular}

表-3 コンクリートの示方配合

\begin{tabular}{|c|c|c|c|c|c|c|c|}
\hline \multirow{2}{*}{$\begin{array}{l}W / C \\
(\%)\end{array}$} & \multirow{2}{*}{$\begin{array}{l}\text { Air } \\
(\%)\end{array}$} & \multicolumn{4}{|c|}{ 単位量 $\left(\mathrm{kg} / \mathrm{m}^{3}\right)$} & \multirow{2}{*}{$\begin{array}{c}\mathrm{SP} \\
\text { 添加量 } \\
(\mathrm{C} \times \%)\end{array}$} & \multirow{2}{*}{$\begin{array}{c}\mathrm{AE} \\
\text { 添加量 } \\
(\mathrm{C} \times \%)\end{array}$} \\
\hline & & $W$ & $C$ & S & $G$ & & \\
\hline 45 & 4.5 & 170 & 378 & 814 & 933 & 0.30 & 0.01 \\
\hline
\end{tabular}

表-4 コンクリートの強度性状

\begin{tabular}{c|c|c}
\hline & $\sigma_{1}(\mathrm{MPa})$ & $\sigma_{28}(\mathrm{MPa})$ \\
\hline 圧縮強度 (標準養生) & 12.7 & 53.4 \\
\hline
\end{tabular}

埋込み長 $-5 \mathrm{~mm}$ は, 塗装の塗替元時に境界部に生じる 塗装の欠陥を想定して定めたものである。

本実験に扮ける使用材料，コンクリートの示方配合扮 よび強度性状をそれぞれ表-2，表-3 㧍よび表-4 に示す。 鋼板には実施工に使用されているSM490 材を使用した。

\section{2 複合サイクル試験}

供試体の促進腐食試験には，塩水噴霧複合サイクル試 験機を使用した（写真-3）。試験条件は図-4に示すとお り, 屋外暴露試験との相関が高いとされている S 6 サイ クル（S60 年通産省）とした ${ }^{8) .9}$ 。各供試体の腐食条件 が均等になるよう試験機内の供試体は定期的にローテー ションさせた。なお，複合サイクル試験開始時のコンク

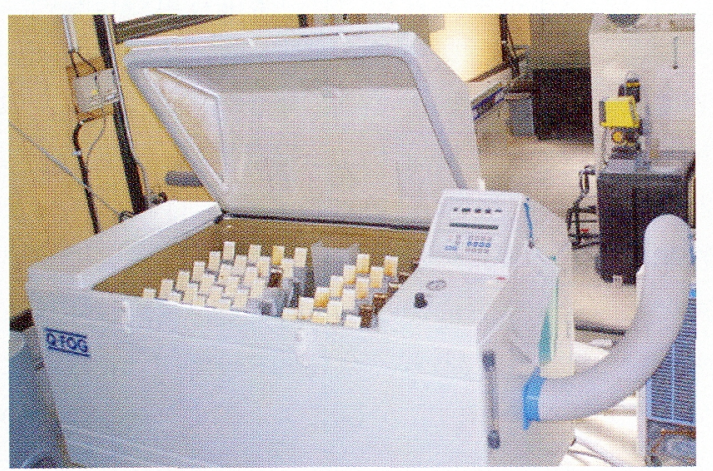

写真-3＼cjkstart複合サイクル試験機

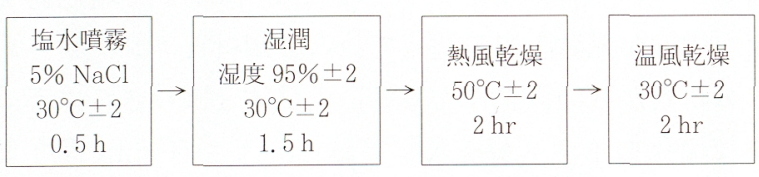

図-4 試験条件 (S 6 サイクル)

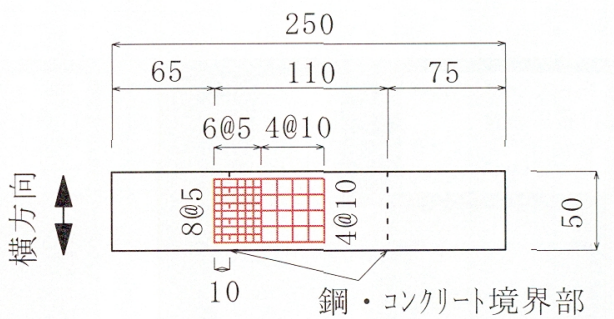

図-5 鋼板厚の測定位置

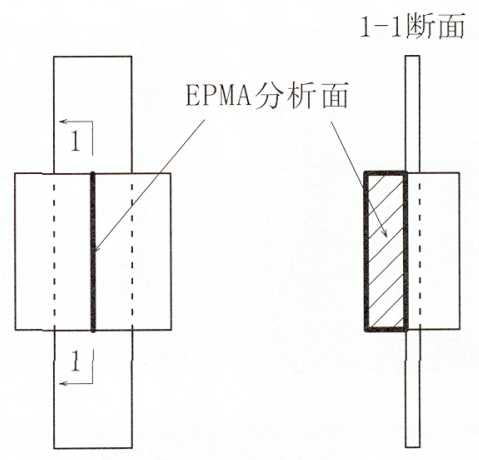

図-6 EPMA 分析面

リートの材齢は 7 日とした。

\section{3 複合サイクル試験後の測定}

複合サイクル試験に打けるサイクル数が $360 \mathrm{cyc} ， 600$ cyc および 720 cyc になった段階で, 供試体を取り出し, コンクリートを割裂した後，内部の観察抢上び鋼板厚の 測定，等を行った。内部の観察扔よび鋼板厚の測定を行っ た供試体の数は，360 cyc で 1 体，600 cycで 3 体，720 cycで 4 体とした。鋼板厚は図-5 亿示すグリッド位置で 測定した。なお，鋼板厚老測定する前には鋼板の除錆 （10\%クエン酸アンモニウム浸せき）を行った。

\subsection{EPMA による分析}

塩化物イオンがどのように接合部の内部へ浸透するか を検討するため， $720 \mathrm{cyc}$ における供試体のコンクリー 卜をEPMA（電子線マイクロアナライザー）により分 析した。分析の対象は, 供試体 3,4 および 7 とし, 分 析面は図-6のと㧍りとした。

\section{3. 実験結果㧍よび考察}

\section{1 コンクリート内部の状況}

各供試体の腐食状況を写真-4 亿示す。写真は各供試 体のうち, 最屯腐食が認められたものを示して抢り, 基 本的には $720 \mathrm{cyc}$ 時の写真であるが，供試体 2 のみ 600 cycで内部を調查したあのの方が腐食していたため, そ ちらを示している。

シーリング材を有する供試体（供試体 1，7）はコン クリート内部の鋼板に腐食は認められないが，それ以外 の供試体はコンクリートの内部の鋼板に腐食か認められ る。シーリング材による止水を行わない場合は，付着の 有無，プライマーの有無にかか⿰力口ず，コンクリート内 部の鋼板が腐食する場合があることを示している。シー 


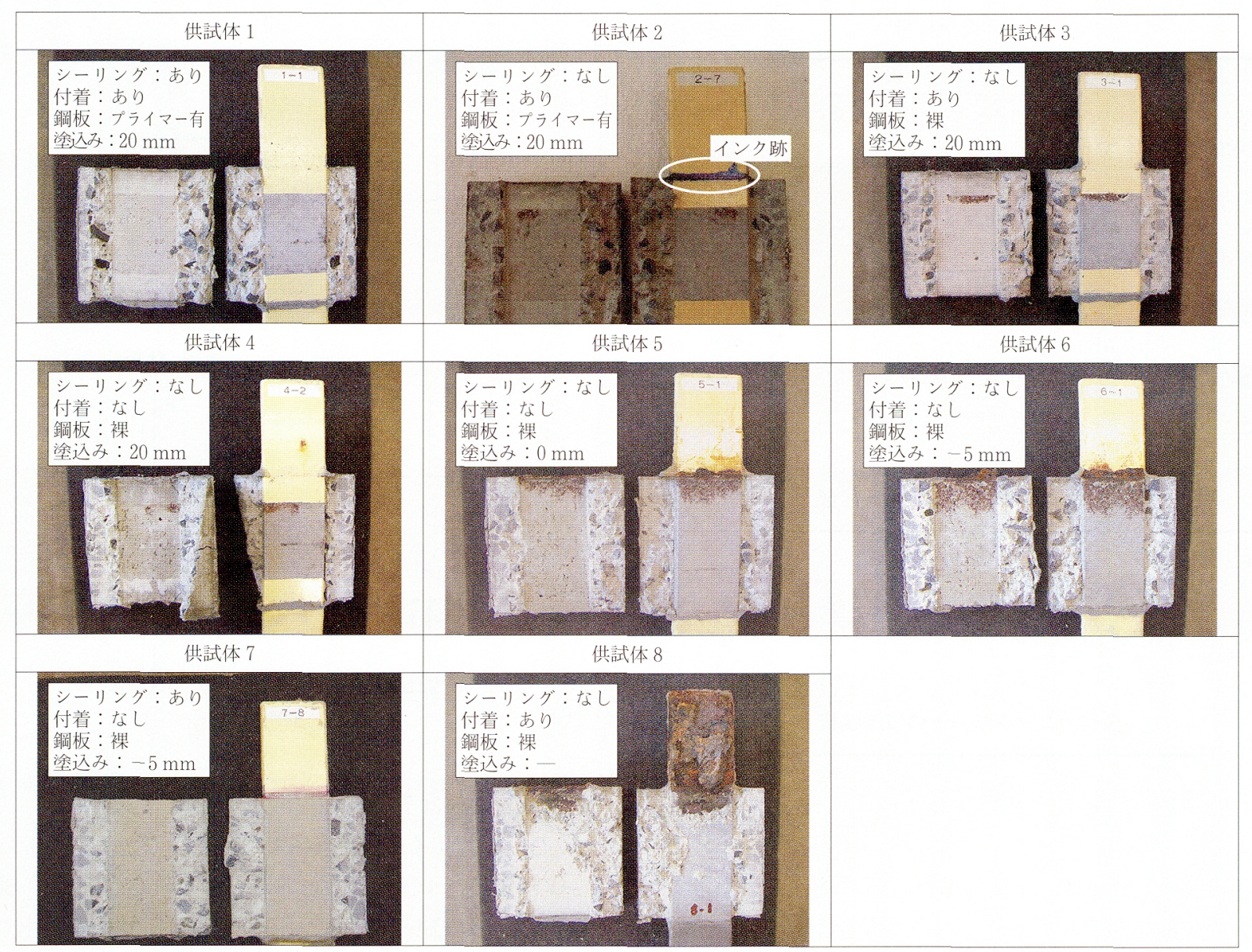

写真-4 供試体の腐食状況

リング材がなく，塗装がコンクリート内部に埋め込まれ た供試体（供試体 2，3，4）に関しては鋼板の腐食は軽 微であるが，塗装がコンクリートの内部に埋め込まれて いない供試体（供試体 5，6）に関しては，鋼板とコン クリートとの境界部（以降, 境界部）からコンクリート 内部に加けて激しく腐食している。以上より，埋込み接 合では，(1)境界部は腐食而久性上の重要な箇所であるこ と，(2)塗装をコンクリートに埋め込むことで境界部の急 激な腐食老防止できること，㧍よび(3シーリング材は埋 込み接合の腐食耐久性を向上させる効果があることが確 認された。塗装の塗替え時なよ゙，境界部の塗装が不十分 となりやすい場合，境界部のシーリング材は重要な役割 を果たすと考えられる。

\section{2 板厚測定結果}

複合サイクル試験後の鋼板厚の減少量を図-7に示す。 測定位置は鋼材とコンクリートの境界部からの距離であ り，正值はコンクリート内部方向在表す。鋼板厚の減少 量は，図-5のグリッド位置で測定した鋼板厚から求め た。塗装を埋込んでいるもしくはシーリング材を施し 境界部に变状のない供試体 $1 ， 2 ， 3 ， 4$ ，打よび 7 につ いては，腐食による鋼板厚の減少はほ上んご認められな い。一方，境界部が腐食していた供試体 5,6 および 8 については鋼板厚の減少が認められ，サイクル数が増え るほど，腐食がコンクリート内部に進行していることが
確認された。これは鋼板とコンクリートとの境界部が腐 食すると，錆の膨張によりコンクリートと鋼板との間に 空隙ができ，塩水が接合部内部に供給されやすくなるた め上考えられる。

\section{3 EPMA 測定結果}

720 cyc 終了後の供試体 3，4，抒よび 7 のコンクリー トについて EPMAにより塩化物イオン濃度を测定した。 コンクリート中の塩化物イオン濃度の分布を図-8に示 す。図中の数字はコンクリートの単位質量あたりの塩化 物イオン濃度を示す。鋼材の発錆限界之いわれる 1.2 $\mathrm{kg} / \mathrm{m}^{3}$ (単位体積あたりの塩化物イオン濃度) は, 単位 質量あたりの濃度に換算すると $0.05 \%\left(=1.2\left[\mathrm{~kg} / \mathrm{m}^{3}\right]\right.$ $/ 2350\left[\mathrm{~kg} / \mathrm{m}^{3}\right] \times 100 ）$ よるるため, 有色の部分は塩 化物イオン濃度が発錆限界を超えていると考えてよい。

複合サイクル試験による塩化物イオンは，コンクリー 卜上端から浸入しており，全体的に上部 $1 \mathrm{~cm}$ 程度に濃 い分布を示している。しかし，コンクリートと鋼板の境 界部付近では，コンクリートの上端から鋼材に沿って塩 化物イオンが浸入しており，鋼材とコンクリートとの付 着がある供試体 3 であ, 深さ $20 \mathrm{~mm}$ 程度まで塩化物イ オン濃度が発錆限界を超えている。鋼材とコンクリート よの付着がない供試体 4 では，供試体 3 上りさらに深く まで塩化物イオンが浸入しており，深さ $50 \mathrm{~mm}$ 程度ま で発錆限界を超えている。一方，シーリング材を設置し 

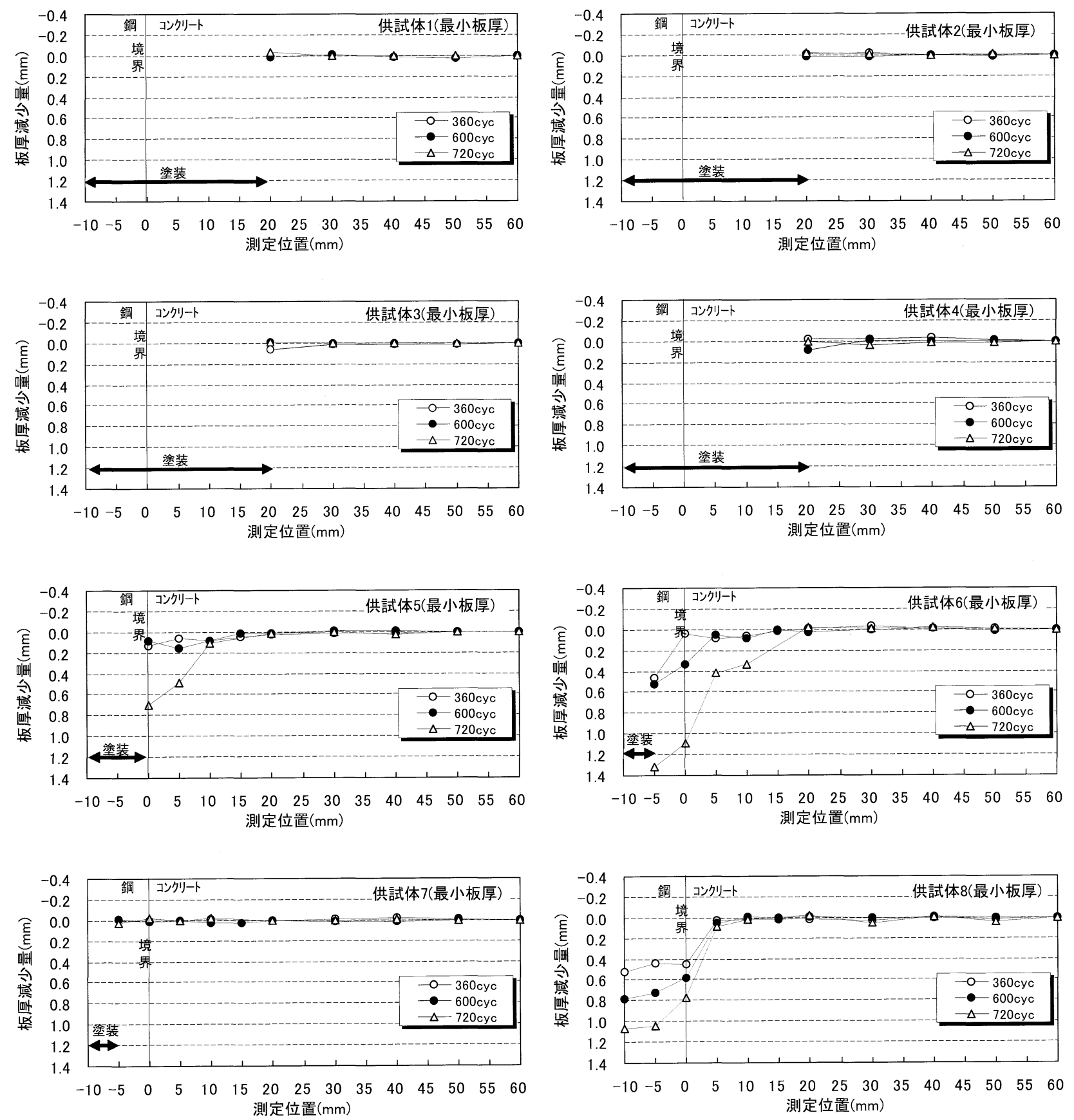

図-7 鋼板厚の減少量

た供試体 7 では, 鋼材とコンクリートとの付着がないに 屯かかわらず，鋼材に沿って浸入した塩化物イオンはほ とんど認められない。これは, シーリング材が, 塩水を 遮断したためであり，シーリング材を設置した供試体で, 鋼材の腐食が認められなかったのはこのためと考えられ る。ところで, 供試体 7 のシーリング材が設置されてい ない部分において, 塩化物イオンがコンクリート内部に 浸入していることがわかる。今回使用したコンクリート の水セメント比は 45\%であるが, 水セメント比がさら に高く, 塩分拡散係数が大きいコンクリートでは, シー リング材が設置されていてもコンクリートを通過して, 塩化物イオンが接合部内部に到達すること屯考えられる。 通常の PC 構造物で使用されるコンクリートでは問題な
いと考えられるが, 塩害環境下で, 強度が低いコンクリー 卜構造物に埋込み接合を使用する場合は，シーリング材 と併せて，接合部付近のコンクリートを表面被覆するな どの対策が必要と考えられる。

\section{4 複合サイクル試験による腐食環境}

今回実施した複合サイクル試験が，どの程度の腐食環 境かを考察するため, 供試体 4（720 cyc 後）のコンク リートを化学分析して, コンクリート中の塩化物イオン 濃度を測定した。供試体 4 のコンクリート中の塩化物イ オン濃度を図-9に示す。塩化物イオン濃度は, 境界面 からコンクリートを $1 \mathrm{~cm}$ の深さごとにスライスし，化 学分析して求めたものである。比較のため塩害地区であ る親不知高架橋付近で屋外暴露されているコンクリート 


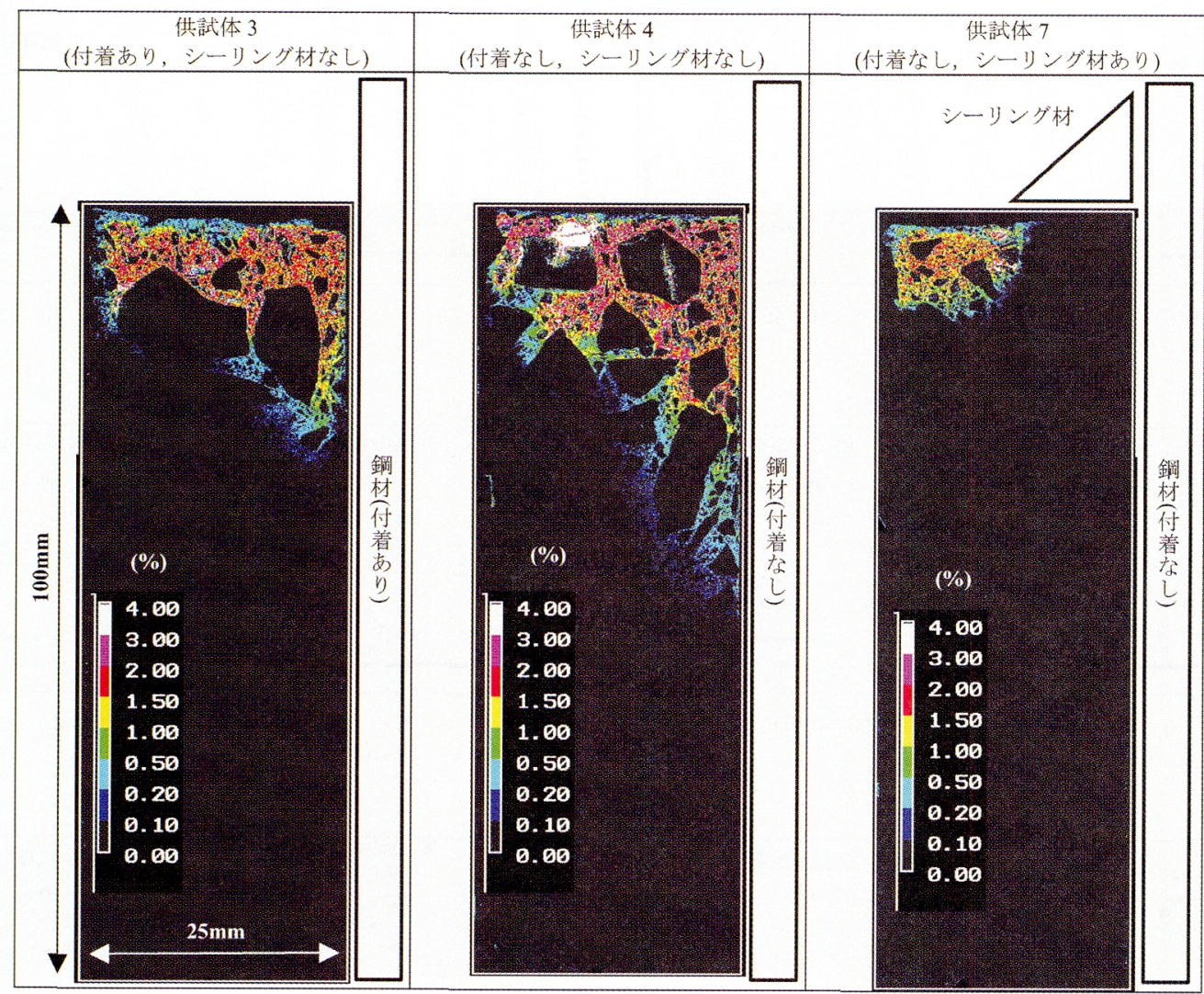

図-8＼cjkstart塩化物イオンの濃度分布

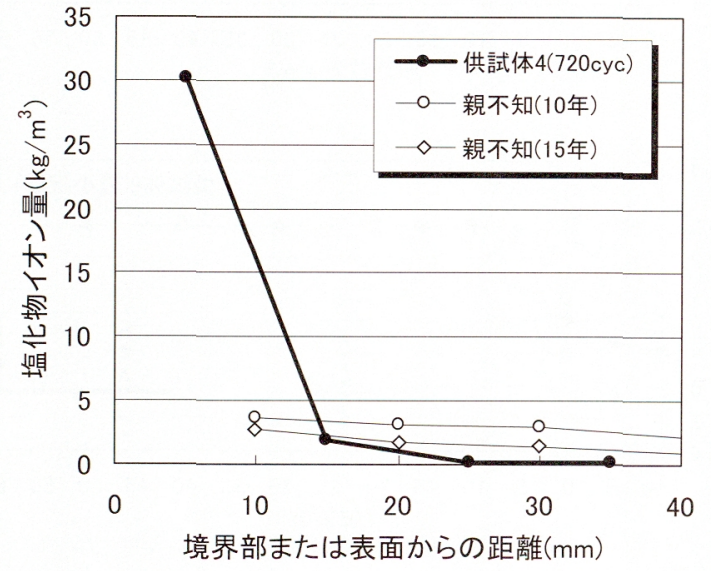

図-9 720 cyc 後のコンクリートの塩化物イオン濃度

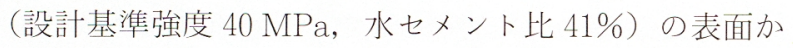
らの塩化物イオン濃度む併せて示す ${ }^{10}$ 。供試体 4 のコン クリート中の塩化物イオン濃度は, 深さ $0 \sim 1 \mathrm{~cm}$ で 30.2 $\mathrm{kg} / \mathrm{m}^{3}, 1 \sim 2 \mathrm{~cm}$ で $2.0 \mathrm{~kg} / \mathrm{m}^{3}$ であり, 境界面からの深 さが $1.5 \mathrm{~cm}$ までの区間に関しては, 塩害地区で 10〜15 年屋外暴露されたコンクリートを超えている。このこと から，今回実施した複合サイクル試験では，境界面から $1.5 \mathrm{~cm}$ の深さに関しては，塩害地区に 10〜15 年暴露し た腐食環境に相当すると推察される。

\section{4. ま と め}

本検討により，埋込み接合部の耐久性に関して，以下 の知見が得られた。
1）シーリング材がなく，塗装がコンクリート中に埋 め込まれていない条件では, 境界部からコンクリー 卜の内部にかけて鋼板が激しく腐食することが確認 された。埋込み接合では，コンクリートと鋼板との 境界部が腐食耐久性上の弱点になる上考えられる。

2）鋼とコンクリートとの境界部が腐食すると，錆の 膨張によりコンクリート上鋼板との間に空隙ができ, 接合部に劣化因子が浸入しやすくなるため，特に激 しい腐食となり，板厚の減少量が大きくなると推察 される。

3）塗装をコンクリート内部にある程度埋め込むこと で境界部の急激な腐食を抑制できる。ただし，シー リング材がない場合は，コンクリートと鋼材の付着 の有無, プライマーの有無, 塗装の埋込み深さにか かわらず，コンクリート内部の鋼材は腐食する場合 がある。

4）シーリング材は水や塩化物イオンなどの劣化要因 在遮断する効果が高く, 埋込み接合の境界部および コンクリート内部の腐食をともに防止できることが 確認された。シーリング材を設置することで, 埋込み 接合部の腐食耐久性は大きく向上すると推察される。

5）波形鋼板ウェブの塗装の塗替えなどで，鋼とコン クリートとの境界部の塗装が不十分となる可能性が 考えられるが，境界部にシーリング材を施すことに より腐食耐久性を確保することが可能と考えられる。 
謝 辞 本報告は，（社）プレストレスト・コンクリー 卜建設業協会之旧日本道路公団試験研究所（現，中日本 高速道路（株）中央研究所）との共同研究（名称：複合 構造橋梁の維持管理に関する共同研究）の成果の一部を まとめたものである。文末ながら，筆者以外の各委員* およびご協力いただいた関係各位に御礼申し上げます。 *宇津木一弘, 長田光司, 紫桃孝一郎, 白谷宏司, 鈴木 永之, 高橋 功, 武知 勉, 立神久雄, 辻 裕治, 中村 定明, 永元直樹, 本荘淸司, 溝江慶久, 谷中 聡 （敬称略 五十音順）

\section{考 文 献}

1）プレストレストコンクリート技術協会：複合橋設計施工規準，技 報堂出版，2005.11

2) 近藤昌泰・清水洋一・小林謹一・服部政昭：波形鋼板ウェブ PC 箱桁橋新開橋の設計と施工，橋梁と基礎，Vol. 28，No. 9, pp. 13 $\sim 20,1994.9$

3）石黒 瓦・村田嘉宏・須合孝雄：松の木 7 号橋（銀山御幸橋）の
設計と施工，プレストレストコンクリート，Vol. 38， No. 5, pp. 5 14, 1996.9

4）水口和之 - 芦塚憲一郎 - 古田公夫 - 大浦 隆 - 滝 憲司 - 加藤卓 也：本谷橋の設計と施工, 橋梁と基礎, Vol. 32 , No. 9 , pp. 2 $10,1998.9$

5）鈴木永之・紫桃孝一郎・桜田道博・立神久雄：波形鋼板ウェブ橋 に打けるコンクリート床版接合部の横方向性状, コンクリート工 学論文集, Vol. 15, No. 1, 2004.1

6）竹下 明・依田照彦ほか：波形鋼板ウェブを有するI形断面合成 桁の埋込み接合部の疲労実験, 土木学会論文集, No. 668, I-54, 2001. 1

7） 中州啓太・依田照彦ほか：鋼板孔のずれ止めを用いた波形鋼板ウェ ブを持つ合成桁の面外曲げ挙動に関する研究，土木学会論文集， No. 647, I -51, 2000. 4

8）貝沼重信・細見直史・金 仁泰・伊藤義人：鋼構造部材のコンク リート境界部における経時的な腐食挙動に関する研究, 上木学会 論文集，No.780，I -70，2005.1

9）藤原 博 - 田原芳雄 : 鋼橋塗装の長期防食性能の評価に関する研 究，士木学会論文集，No. 570, I -40, 1997.7

10）横山和昭・大橋 岳・松田哲夫・青山實伸：塩害環境下のコンク リート橋に適用した塩害対策の追跡調查, コンクリート工学, Vol. 42, No. 3, 2004.3

\section{お知らせ}

\section{第 22 回 材料・構造信頼性シンポジウム講演募集}

主催：(社)日本材料学会

協賛：(社)日本コンクリート工学協会 他

1. 期日：2006 年 12 月 5 日（火），6日（水）

2. 場所：東京大学山上会館

3. 講演募集分野

干113-8654 東京都文京区本郷 7-3-1

A．材料信頼性，B．構造信頼性，C．リスク・マネージメント，D．品質管理，E．実機・実製品の信頼性保証，F．データベー ス・デー夕解析，G．地震・応答解析，H. 防災基盤技術，I. 災害・事故解析，J. LCA ・管理計画，K．損傷検查・管理技術， L. 信頼性・社会基盤技術, M. 航空宇宙構造物の信頼性, N. 信頼性理論, O. 不規則振動解析, P. その他

4. 講演申込締切：2006 年 9 月 15 日（金）

5. 講演原稿締切：2006 年 10 月 27 日（金）

6. 参加登録料
（1）会 員：3000円
（2）非会員：5000円
(3) 学生会員：1000 円
(4) 学生非会員：2000 円

\section{7. 講演論文集}

会員：3000 円, 非会員 : 5000 円, 学生：1000 円

8. 申込み・問合せ先 :

愛知大学工学部機械工学科 桂 三佳

干790-8577 愛媛県松山市文京町 3

FAX : 089-927-9734

E-mail :sympo2006@zairiki.me.ehime-u.ac.jp

9. その 他

信頼性工学部門委員会ホームページ（http://www.sinrai.jsms.jp/index.html） 